\title{
Wild rights: A tribute to wolves
}

Strange and strong

pulses the wild heart

\section{A voice to the moon}

powerful, reverberating, silver

then thin,

her frost spangled face

white, grey, soft... fey,

she waits...

paws quilted... lifted

With eyes like ice - she gazes

through her reflection

into the blackening water,

tracking a trout

she slips down a drift

in a spine-twisting pirouette,

splintering icicles scatter,

disarming the night

the rhythm of a fresh fall

\section{At the furthest border}

of a campfire

the briery pelt,

tail... white tipped and turbulent,

rime flecked face,

her gaze - absorbed, rapt ... responsive

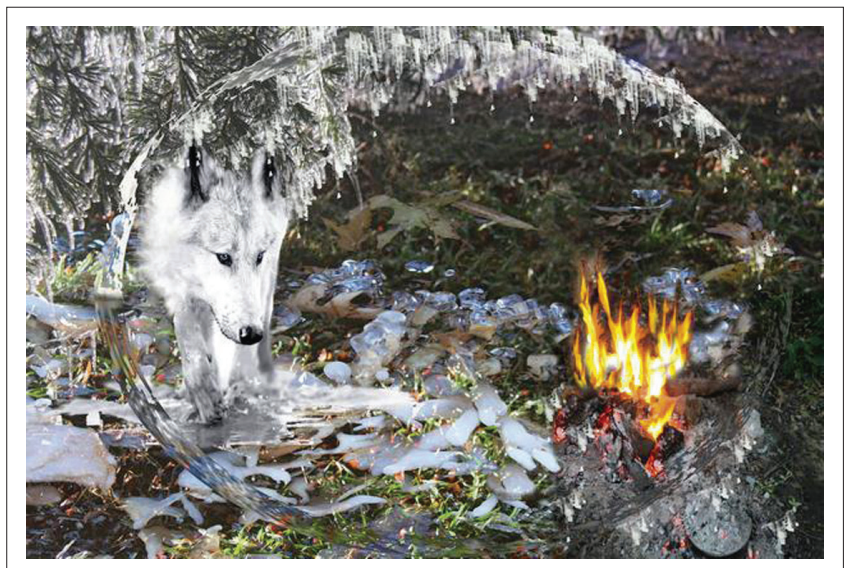

Source: This photo is used with the permission of the author and photographer, Patricia

G. Maritz

FIGURE 1: Wild rights: A tribute to wolves.

\begin{tabular}{lll}
\hline Read online: & $\begin{array}{l}\text { Author: Patricia G. Maritz }{ }^{1} \\
\text { Affiliation: }{ }^{1} \text { Department of Philosophy, University of Zululand, South Africa } \\
\text { Email: patricia.maritz@gmail.com }\end{array}$ \\
$\begin{array}{ll}\text { Scan this QR } \\
\text { code with your } \\
\text { smart phone or } \\
\text { mobile device } \\
\text { to read online. }\end{array}$ & $\begin{array}{l}\text { Postal address: Private Bag X1001, KwaDlangezwa 3886, South Africa } \\
\text { How to cite this article: Maritz, P., 2015, 'Wild rights: A tribute to wolves', Literator 36(1), Art. \#1132, } 1 \text { page. http://dx.doi.org/10.4102/lit. } \\
\text { Copyright: @ 2015. The Authors. Licensee: AOSIS OpenJournals. This work is licensed under the Creative Commons Attribution License. }\end{array}$
\end{tabular}

